\title{
Reflections on the Evolution of Legal Systems in the Canadian North
}

\section{Ken Coates*}

There is a tendency, perhaps primarily among non-lawyers and the general public, to see the law—and justice, its apparent near synonym — as fixed and unchanging concepts. There is a general belief that certain actions, such as murder and robbery, are inherently wrong and are unacceptable in all societies at all times. We know that laws, legal processes, and punitive systems are created to provide structure for the regulation, control, and sanctioning of human behaviour, and, in the process, to keep a society safe, secure, and untroubled. This seems relatively straightforward. The reality, of course, is far more complicated. As societies change and become more diverse, the law morphs into something much more intricate.

Working with my colleagues on this special issue of the Northern Review focused on law in the Canadian North brought home the importance of understanding the broader contexts of the law and legal processes. For practitioners, the nature of the law has true immediacy and significant real-world consequences, and must be understood in terms of existing processes, efficiencies, strengths, and weaknesses. For academics immersed in the theory and concepts such as crosscultural equity, fairness, and effectiveness, the law and legal systems are to be investigated and challenged. Both exercises are valuable, for the system must be managed and adjusted appropriately while the larger questions are explored. 
Modern legal systems are remarkably convoluted, addressing human behaviour, corporate activities, and government-individual and government to government relationships. The simplistic formulation, that the law equals justice or the written rules, is far removed from the day to day realities, as legal practitioners and academics well know. The northern legal landscape is further complicated by a network of overlapping legal systems. These include dozens of distinct mechanisms, from the legal traditions of several Indigenous Peoples, for social control, adjudication of disputes, and sanctions for breaking community norms; Canadian laws imposed incrementally on the North starting in 1870; international and diplomatic conventions and treaties that go back to the nineteenth century and continue to the present; and the American legal system imposed in Alaska starting in 1867 . These systems have been changed, more recently, by land claims settlements across the North, which have provided opportunities for various models of Indigenous governance, and for creativity in adapting judicial and legal systems (Haycox, 2017).

\section{The Evolution of Legal Systems in the Canadian North}

It is vital, therefore, to see "the law" as a process rather than a specific structure or set of rules and conventions. Values change over time, as the long-term criminalization of marijuana and more recent legalization indicate. So it is with domestic violence, a painful social problem that is now taken much more seriously by the police and courts than in the past. Environmental assumptions and, therefore, regulations, have shifted profoundly, requiring new processes of oversight, enforcement, and penalties. More profoundly, the growing recognition of the inherent jurisdiction of Indigenous governance, and the importance of Indigenous cultures, values, and social systems in Canada, along with the Truth and Reconciliation Commission's findings and calls to action, have challenged everything from the nature of northern policing and enforcement, to judicial and oversight processes, and even the fundamentals of law-making and governance.

At first glance, "the law" is about the development and application of rules at multiple social levels (community, regional, national, and global), and is designed to ensure that our individual and collective behaviours are aligned with the cultural norms and expectations of Canadian society. In reality, the law is an area of constant contestation. Values change, relationships between cultures and societies evolve, international contexts shift, government leadership passes between political parties, and new court decisions respond to shifts in social norms and depart from established legal precedents. Discussions on legal reform and 
improvement of legal processes are grounded in the understanding that the law must not be something that is fixed in place and immutable. Most importantly, the law is a culturally embedded phenomenon (Borrows, 2005), generally reflecting the values of the dominant society, and a human construct.

\section{The Persistence of Indigenous Legal Traditions}

For many centuries, likely millennia, Indigenous Nations across the Canadian North developed unique laws and legal traditions, tied to traditional territories, and informed by relationships, the land, the animals, and the spirit world. The many Indigenous Peoples of the Canadian North—such as the Dene, Gwich'in, Inuit, Innu, Inuvialuit, Tlingit, Tutchone, among others-each had distinct legal traditions for social control, dispute resolution, sanctions, and rehabilitation, according to their respective cultures and values. These systems did not look like the British-Canadian rules that came later, based on the British cultural traditions, with police forces, jails, judges, and written legal codes. So when the first Europeans arrived in the area, they paid little attention to the existing Indigenous social codes, protocols, and laws. They failed to recognize the legitimacy of the Indigenous legal orders and, conceptually more than practically, insisted on Indigenous Peoples' respect for the new legal regime. However, for the Indigenous Peoples in the North, who had little direct contact with the newcomers and who managed their own affairs for generations after the arrival of the Europeans, their cultural traditions, not those of the Europeans, continued to dominate social relationships and legal orders; the Indigenous systems remained intact and operational (Borrows, 2005, 2002, 1996; (Hanna, 2019; Napolean, 2007; Ryan, 1995; McClellan and Birckel 1987).

\section{The Imposition of British-Canadian Law}

Europeans imposed both their world view and their laws on the North years before they actually arrived throughout the region, by establishing boundaries and their legal culture, and, eventually, sending representatives to enforce these foreign-created rules. A long era of adaptation followed. Given the realities of law enforcement and regulation in a vast and thinly populated land, distant governments moved slowly to impose their laws, knowing that moving too quickly would undermine the credibility of the new order. This applied equally to the Indigenous populations, whose rules and processes were being respected, if only because of the inability and lack of interest of governments to supervise legal matters effectively across the North before the middle of the twentieth century (Coates, 1987; Wright, 1976). 


\section{The Limits of Canadian Law in the North}

Canadian "law" arrived in the Yukon in the form of the North-West Mounted Police (NWMP), who reached the upper Yukon River basin in 1894. Before that time, the miners regulated their affairs through loosely coordinated miners' meetings. When a significant crime occurred or if legal issues needed to be resolved, a community member would call a meeting. Evidence would be heard and the group would collectively issue a judgment, when warranted, which was binding on the individuals involved. With the arrival of the police, and then the first Yukon judge appointed by the Canadian government in 1897, the miners' meeting disappeared as a community force in the North.

During the Klondike Gold Rush, the government ramped up the police presence in the areas affected by the arrival of the stampeders (Morrison, 1974). During the gold rush, Canadian authorities proved adaptable and flexible. They insisted on some symbolic Canadian regulations (banning work on Sundays, for example); ignored manylaws of social control (governing prostitution and gambling, for instance); and worried about the overwhelming dominance of the American population in the region. The system worked, in large measure, because the miners feared social disorder more than all else and appreciated the professionalism and adaptability of the police. Meanwhile, the force, led by Inspector Charles Constantine, knew that the Government of Canada lacked the resources and the will to enforce Canadian authority systematically. The government withdrew most of the police from the North when the gold rush abated.

In the decades that followed, and until the Second World War, the NWMP and then the Royal Canadian Mounted Police (RCMP) maintained a skeletal presence across the Territorial North. Long patrols by a handful of police constables represented the sum total of the presence of the Canadian legal system in the vast majority of the North. The government moved slowly to implement and enforce Canadian law, relying on a small number of high-profile murder cases and "show" trials to make it clear that Canadian authority ruled in the North (Coates and Morrison, 2004; Coates and Morrison, 1998). To a very substantial degree, Indigenous social, cultural, and legal practices and processes continued to operate among Indigenous Peoples across the North. Formal Canadian laws applied to the non-Indigenous populations and governed commercial relations and the mining sector, but in the Yukon, for example, there was a small police presence and limited reach of the Canadian courts outside the Whitehorse-Dawson City corridor.

While Canada did little more than what historian WR Morrison has described as "showing the flag" (Morrison, 1985) there was at least little collective 
doubt both that Canadian law governed the North and, second, that Canadian law enforcement was minimally effective. Without formal recognition by the nation state, Indigenous legal and social orders, traditions, values, and processes held sway over much of the North, which was managed by the Government of Canada with an approach best described as hands-off and non-interventionist (Foster and McLaren, 1995; Coates, 1991; McCandless, 1985; Morse, 1985; Stone, 1988; Stone, 1983; Stone 1983b; Stone, 1979; Finkler, 1976).

\section{American Extraterritoriality}

The onset of the Second World War introduced the most unusual era in the Yukon's legal history. Tens of thousands of American soldiers and civilians (plus many Canadian civilians) entered the region in 1942 to work on the Alaska Highway and the other northwest defence projects. The "friendly invasion" swept through the Yukon and along the Mackenzie River Valley, upsetting the social and political order almost overnight. The Government of Canada's legal and administrative presence in the region was distressingly small. There was no capacity to supervise and control the more than 40,000 Americans in the Canadian Northwest.

Recognizing their limited authority in the region, the Government of Canada accepted American demands for extraterritoriality, which allowed the United States Armed Forces to handle the legal affairs of their military personnel and civilians. While the RCMP had a small presence in the area, and while Canadian courts still operated, the American majority fell under foreign control. The new arrivals were largely focused on their time-sensitive construction work and incidents were comparatively few in number. But there were instances of American personnel accused of serious crimes being spirited out of the country and charged and sentenced under US military law-with a lower standard of proof and more severe penalties than Canadian law. American extraterritoriality ended when the Americans withdrew their troops and civilian operators at the end of the Second World War (Coates and Morirson, 2015; Coates and Morrison, 1991).

\section{Arctic International Law and Policy}

Two quite different processes redefined legal regimes and relationships in the post-Second World War era. The first relates to international and diplomatic affairs, both growing in importance through the Cold War and continuing to the international collaborations on climate change. There has been a surge in the role of circumpolar accords and institutions. The work began in earnest with the formation of the Inuit Circumpolar Council in 1977, which has seen Inuit from across the Circumpolar North share their experiences, priorities, and ideas, and 
work toward common solutions. It has continued through the establishment of the Arctic Council in 1996, which has since provided a forum for circumpolar planning, policy making, and agreements without formal legislative or binding authority. The growing importance and role of international accords in the region have included the United Nations Convention on the Law of the Sea (which came into force in 1994), and the Arctic Search and Rescue Agreement amongst Arctic states (which came into force in 2013) among many other agreements, which have led to the emergence of the Circumpolar North as perhaps the most significant and successful region in the world in terms of intra-regional legal collaboration and problem solving (Coates and Broderstad, 2019; Sidorova, 2019; Wilson, 2019; Bankes, 2019,1980; English, 2013; Shadian, 2018; Byers, 2013; Coates et al, 2010; Rothwell, 1996; Sanders, 1983).

\section{Re-Engaging with Indigenous Law}

The second process redefining legal relationships since the Second World War involves the recognition of Indigenous legal and social systems in Canada. This is the opposite of high-level, international collaboration and involves culture-specific reempowerment. These processes are partial, incomplete, and implemented unevenly across the Canadian Territorial North. But through the completion of modern treaties and re-establishment of Indigenous governance, adaptations by territorial, provincial, and federal legal systems are underway to incorporate Indigenous concepts, values, and methods of reconciliation and compensation. These values, protocols, and traditions, preserved in the wisdom of Elders and the practices of communities, are now being recognized, slowly reconciled with Western legal traditions, and integrated into a broader and more complex Canadian system of social control and relations (Borrows, 2020; Mills, 2016; Napoleon and Friedland, 2014; Case and Voluck, 2012; Richardson et al., 2009; Grammond, 2009; Gunn, 2007; Loukacheva, 2007; Patenaude, 1989; Carswell, 1984).

\section{Co-Creating Northern Law and Justice}

Law, policing, and legal processes in the Canadian North have become among the most creative, flexible, and multicultural in the world. The transitions range from the use of Indigenous translators and cultural specialists in court proceedings; the adoption of Indigenous sanctions and practices such as sentencing circles; crossthe integration of Indigenous historical experiences into the sentencing processes; cultural and transnational negotiations on new regulations and processes, such as territorial and state involvement with Arctic Council work on environmental monitoring and Arctic search and rescue; the recognition of Indigenous systems for sanctions, compensation, and rehabilitation; new models of Indigenous policing; 
and many others. As with so many aspects of northern public life, the northern legal community is responding to these transitions and associated pressures with a tiny professional and legal class, an overburdened political and administrative system, and a policy and program agenda that is dominated by a wide variety of community crises and challenges (Wright, 2002).

There are complicated processes involved with coordinating northern Canadian arrangements with those in the broader Circumpolar World and, equally, with reconciling Indigenous legal traditions and orders with the Canadian legal system. These are truly formidable challenges and the solutions will work out over generations rather than years. Nonetheless, the legal transformation has been remarkable, going from the imposition of foreign legal structures and processes in the nineteenth century, through to the reassertion of Indigenous values and traditions over the past half century.

Without drawing much attention to the collective and quiet evolution of northern law and justice, governments, Indigenous nations, police, judges, and court and prison officials are in the process of co-creating a new northern legal system. The system remains dominated by British-Canadian paradigms and structures, but there is growing evidence of flexibility and cultural learning (Coates $\&$ Poelzer, 2016). The impact of land claims settlements, Indigenous governance, and policy-learning in the newly empowered, post-devolution northern territories, and growing judicial openness to Indigenous norms and laws is clearly being felt. In the coming decades, based on genuine political and judicial interest in reconciliation and Indigenous engagement, the North will be well along the way toward the shared creation of a multicultural system of law and justice that reflects the cultures, histories, values, and political realities of the diverse peoples who now inhabit the Territorial North in Canada.

\section{References}

Bankes, N. et al. (2019). The United Nations Convention on the Law of the Sea and the Arctic Ocean. In K. Coates and C. Holroyd (Eds.), The Palgrave Handbook of Arctic Policy and Politics (pp. 375-391). Palgrave.

Bankes, N. (1980). The international law of shared natural resources: A case study of an international wildlife range between Alaska and the Yukon. (Dissertation). University of British Columbia, Vancouver.

Borrows, J. (2005). Indigenous legal traditions in Canada. Washington University Journal of Law E Policy, 19, 167-223. https://openscholarship.wustl.edu/ law journal law policy/vol19/iss1/13.

Borrows, J. (2002). Recovering Canada: The resurgence of Indigenous law. University of Toronto Press. 
Borrows, J. (1996). With or without you: First Nations law (in Canada). McGill Law Journal, 41, 629. https://www.aboriginallegal.ca/assets/withorwithoutyou.pdf.

Byers, M. (2013). International law and the Arctic. Cambridge University Press. https://doi.org/10.1017/CBO9781107337442.

Carswell, M. (1984). Social controls among the Native peoples of the Northwest Territories in the pre-contact period. Alberta Law Review, 22(2), 303-308. http://www.canlii.org/t/sn0c.

Case, D.S., and D.A. Voluck. (2012). Alaska Natives and American laws. University of Alaska Press.

Coates, K. (1991). Best left as Indians. McGill-Queen's University Press.

Coates, K. (1987). Controlling the periphery: The territorial administration of the Yukon and Alaska, 1867-1959. The Pacific Northwest Quarterly, 78(4), $145-151$.

Coates, K., and Broderstad, E.G. (2019). Indigenous Peoples of the Arctic: Retaking control of the Far North. In K. Coates and C. Holroyd (Eds.), The Palgrave Handbook of Arctic Policy and Politics. Palgrave.

Coates, K., and Morrison, W.R. (2015). The Alaska Highway in World War II: The US army of occupation in Canada's Northwest. University of Oklahoma Press.

Coates, K. and Morrison, W.R. (2004). Strange Things Done: Murder in Yukon History. McGill-Queen's University Press.

Coates, K. and Morrison, W.R. (1998). 'To make these tribes understand': The trial of Alikomiak and Tatamigana. Arctic, 51(3), 220-230.

Coates, K., and Morrison, W.R. (1991). The American rampant: Reflections on the impact of United States troops in allied countries during World War II. Journal of World History, 2(2), 201-221.

Coates, K., Lackenbauer, P.W., Morrison, W.R., \& Poelzer, G. (2010). Arctic front: Defending Canada in the far north. Dundurn.

Coates, K., \& Poelzer, G. (2016). From treaty peoples to treaty nation: A road map for all Canadians. UBC Press.

English, J. (2013). Ice and water: Politics, peoples and the Artic Council. Penguin Canada.

Grammond, S. (2009). The reception of indigenous legal systems in Canada. In A. des Ormeaux (Ed.), Multijuralism: Manifestations, Causes, and Consequences (pp. 45-76). Routledge.

Gunn, B. L. (2007). Protecting Indigenous Peoples' lands: Making room for the application of Indigenous Peoples' laws within the Canadian legal system. Indigenous Law Journal, 6, 31-69. http://hdl.handle.net/1807/17134. 
Finkler, H. W. (1975). Inuit and the administration of criminal justice in the Northwest Territories: The case of Frobisher Bay. Ottawa: Department of Indian and Northern Affairs.

Foster, H., and McLaren, J. (Eds.) (1995). Essays in the History of Canadian Law: The Legal History of British Columbia and the Yukon. University of Toronto Press.

Hanna, A. (2019). Reconciliation through relationality in Indigenous legal orders. Alberta Law Review, 56(3), 817-839. https://doi.org/10.29173/alr2524.

Haycox, S.W. (2017). Alaska: An American colony. University of Washington Press.

Loukacheva, N. (2012). Indigenous Inuit law,"Western" law and northern issues. Arctic Review, 3(2), 200-217. https://arcticreview.no/index.php/arctic/article/view/33.

Loukacheva, N. (2007). The Arctic promise: Legal and political autonomy of Greenland and Nunavut. University of Toronto Press.

McCandless, R.G. (1985). Yukon wildlife: A social history. University of Alberta Press.

McClellan, C., and Birckel, L. (1987). Part of the land, part of the water: A history of the Yukon Indians. Douglas \& McIntyre.

Mills, A. (2016). The lifeworlds of law: On revitalizing indigenous legal orders today. McGill Law Journal/Revue de droit de McGill, 61(4), 847-884.

Morrison, W.R. (1985). Showing the flag, The mounted police and Canadian sovereignty in the North, 1894 - 1925. UBC Press.

Morrison, W.R. (1974). The North-West Mounted Police and the Klondike Gold Rush. Journal of Contemporary History, 9(2), 93-105.

Morse, B. (1985). Aboriginal peoples and the law. Carleton University Press.

Napoleon, V., and Friedland, H. (2014). Indigenous legal traditions: Roots to renaissance. In M. Dubber and T. Hörnle (Eds.), The Oxford Handbook of Criminal Law (pp. 225-247). Oxford University Press.

Napolean, V. (2007). Thinking about Indigenous legal orders and law. The National Centre for First Nations Governance. http://www.fngovernance.org/ncfng research/ val napoleon.pdf.

Patenaude, A.L. (1989). Whose law? Whose justice?: Two conflicting systems of law and justice in Canada's Northwest Territories. (Doctoral Dissertation). Simon Fraser University, Vancouver.

Richardson, B.J., Imai. S., \& McNeil, K. (2009). Indigenous peoples and the law: Comparative and critical perspectives. Hart Publishing.

Rothwell, D.R. (1996). The polar regions and the development of international law. Vol. 3. Cambridge University Press.

Ryan, J. (1995). Doing things the right way: Dene traditional justice in Lac La Martre, NWT. University of Calgary Press.

Sanders, D. (1983). The re-emergence of indigenous questions in international law. Canadian Human Rights Year Book, 3-30. 
Shadian, J.M. (2018). Indigeneity, sovereignty, and Arctic Indigenous internationalism. In M. Nuttall. T. Christensen, M. Siegert (Eds.), The Routledge Handbook of the Polar Regions. Routledge.

Sidorova, E. (2019). Circumpolar indigeneity in Canada, Russia, and the United States (Alaska): Do differences result in representational challenges for the Arctic Council? Arctic 72(1), 71-81.

Stone, T. (1988). Miners' justice: Migration, law, and order on the Alaska-Yukon Frontier, 1873-1902. P. Lang.

Stone, T. (1983). Atomistic order and frontier violence: miners and whalemen in the nineteenth century Yukon. Ethnology, 22(4), 327-339.

Stone, T. (1983b). Flux and authority in a subarctic society: The Yukon miners in the nineteenth century. Ethnobistory, 30, 203-216.

Stone, T. (1979). The Mounties as vigilantes: Perceptions of community and the transformation of law in the Yukon, 1885-1897. Law and Society Review, 14(1), 83-114. https://doi.org/10.2307/3053110.

Wilson, Gary. (2019). Indigenous Internationalism in the Arctic. In K. Coates and C. Holroyd (Eds.), The Palgrave Handbook of Arctic Policy and Politics (pp.27-40). Palgrave.

Wright, Allen A. (1976). Prelude to bonanza: the discovery and exploration of the Yukon. Gray's.

Wright, S. (2002). The Akitsiraq Law School: A unique approach to Indigenous legal education. Indigenous Law Bulletin 5(19), 14-17.

Ken Coates is professor and Canada Research Chair in Regional Innovation, Johnson Shoyama Graduate School of Public Policy at the University of Saskatchewan; fellow, Royal Society of Canada; and a founding and senior editor of the Northern Review. 